The BDJ News section accepts items that include general news, latest research and diary events that interest our readers. Press releases or articles may be edited, and should include a colour photograph if possible. Please direct your correspondence to the News Editor, Arveen Bajaj at the BDJ, 64 Wimpole Street WIG 8YS or by email to bdj@bda.org

\section{Indemnity insurance for all dentists?}

\section{(DH) Department of Health}

A Department of Health (DoH) consultation paper is proposing to make it a registration requirement for all dentists to have indemnity insurance.

The consultation paper 'Strengthening the General Dental Council: A paper for consultation' proposes a Section 60 Order to amend the Dentists Act 1984 to allow the GDC to require all dental professionals, on application and on renewal of registration, to provide it with evidence that they have valid indemnity insurance.

The requirement is intended to make it less likely that a dentist who harmed a patient would turn out to be uninsured and unable to pay compensation. Currently dentists are not required by law to have indemnity insurance before they can be registered. Instead, the GDC lays down in its professional standards that a registered person must have indemnity insurance.

Through this order, dentists would be required by law to have indemnity insurance before registration, bringing them into line with osteopaths and chiropractors. Any dentist whose insurance policy expired would have to notify the Council and non-compliance could result in disciplinary action by the Council.

The closing date for the consultation period was the end of October 2004 and the responses will be analysed and used to compile a report. It is subject to the affirmative procedures under which it must be the subject of debates in both Houses of Parliament at Westminster after which the draft Order will then be laid before the UK Parliament and the Scottish Parliament with a report on the consultation.

It will be posted on the DoH's website at www.dh.gov.uk/ Consultations/LiveConsultations/fs/en).

\title{
A run for your money
}

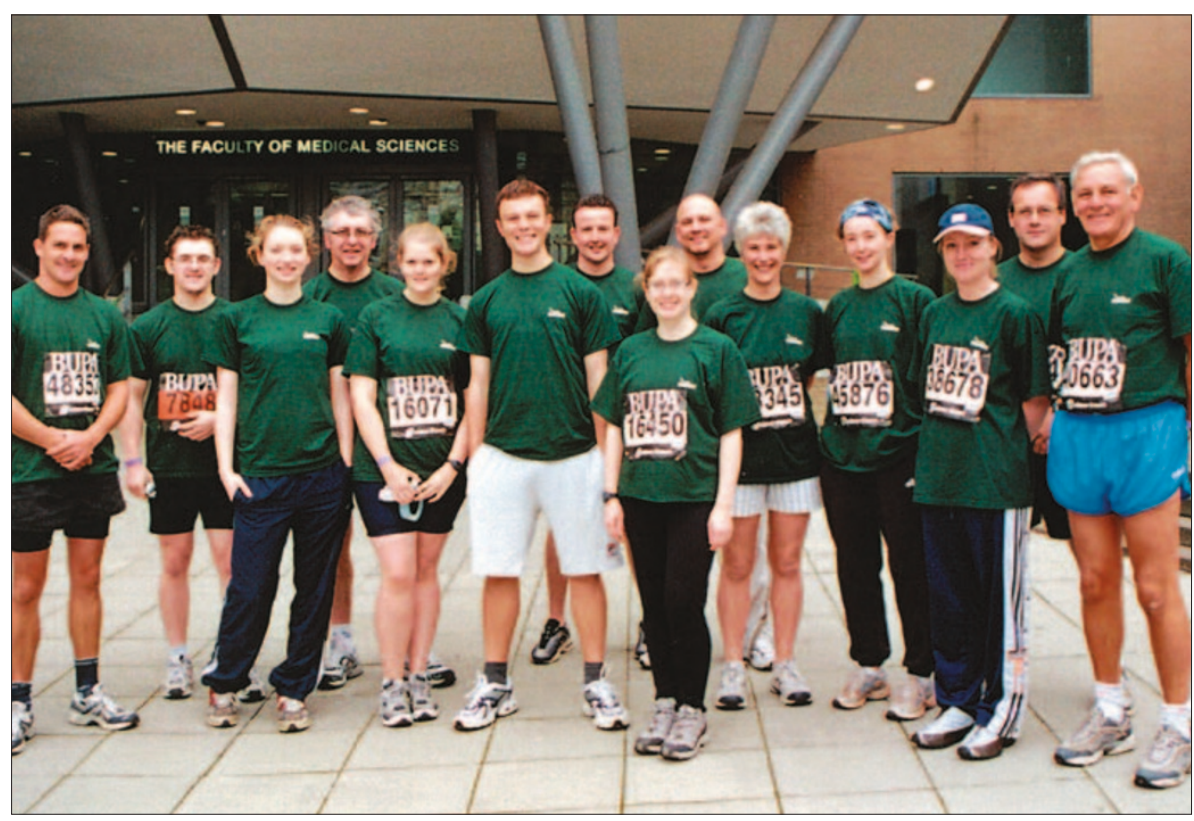

Around 35 dentists, dental nurses and keen supporters donned green t-shirts to run 13 miles on behalf of dental charity Dentaid in the Great North Run, raising funds of $£ 10,000$. The money will be used to fund surgeries and oral health programmes all over the developing world.

\section{Six-monthly dental check-up's replaced}

Regular six-monthly dental check-up's are to be replaced with a new system where the frequency of dental check-ups will be determined by each patient's specific needs.

This is according to new guidelines launched by the National Institute for Clinical Excellence (NICE) this month. The guidelines recommend that for under 18's, the interval between check-up's should be between 3 and 12 months and for adults it should be between 3 and 24 months.

During the check-up a member of the dental team (led by the dentist) will be asked to go through a checklist of modifying factors with the patient that could affect the patient's dental health, such as medical and social history and dietary habits. The recall period for the next check-up will be determined on the basis of the assessment of disease levels and risk of or from dental disease.

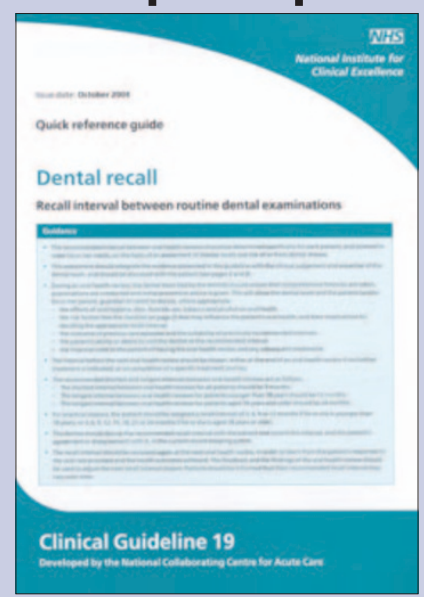

Six-monthly dental check-ups have been customary in the UK since the inception of the NHS, however according to Chief Dental Officer Raman Bedi, these are no longer neccessary as a result of increasing use of fluoride toothpaste and improved oral health education. 


\section{DIARY}

January 2005

OSAP 4th Annual Intermediate-Level Infection Control and Occupational Safety and Health Course

Date: 24-27.01.04

Venue: Hyatt Regency Atlanta, Georgia Tel: 800-298-OSAP (6727)

www.osap.org.

International Dental Foundation 54th International Alpine Dental Conference Date: 29.01.05-05.02.05

Venue: Hotel Annapurna, Courcheval 1850, France

Contact: Robert Wallace

Tel: +44 (0) 2072350788

Fax: +44 (0) 2072350767

Email:idf@idfdentalconference.com www.idfdentalconference.com

\section{March 2005}

83rd General Session \& Exhibition of the IADR, 34th Annual Meeting of the AADR, 29th Annual Meeting of the CADR

Date: 9-12.03.05

Venue: Baltimore Convention Centre www.dentalresearch.org

\section{April 2005}

Academy of Laser Dentistry Source 2005: Lasers in Dentistry

Date: 6-9.04.05

Venue: New Orleans Marriott Hotel, New Orleans, Louisiana, USA

Tel: 1-877-527-3776

Email:memberservices@

laserdentistry.org

www.source2005.org

\section{Raising professional standards}

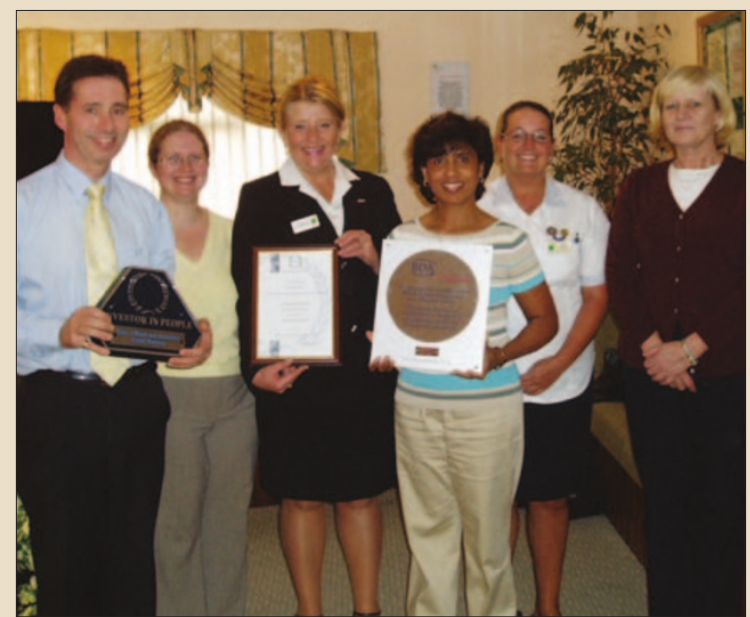

Peter Nixon's dental practice in Intake, Doncaster is the first general dental practice in the area to receive the Investor in People standard. It also achieved the standard for the British Dental Association's Good Practice Scheme at the end of last year. The practice has recently organised a number of internal aims to raise its professional standards, such as training, peer review and clinical audit and all staff have been encouraged to participate.

A North Devon dental practice has recently been recognised as an Investor in People. Queen Ann's Dental Practice in Bideford has refined its systems of management and training to progress the business. Founded in 1923, the mainly private practice employs a team of 15 staff and is led by partners Chris Norburn, Jonathan Hellyer and lain Mackenzie. The staff claim that they have been brought together as a team as a result of the liP and that it has helped them focus on delivering higher standards of care to their patients.

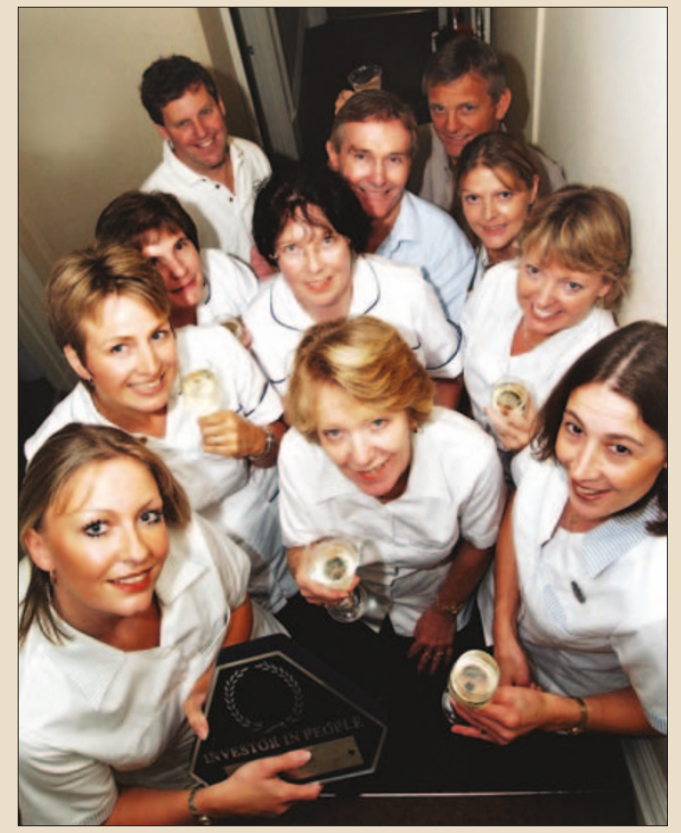




\section{Double award success}

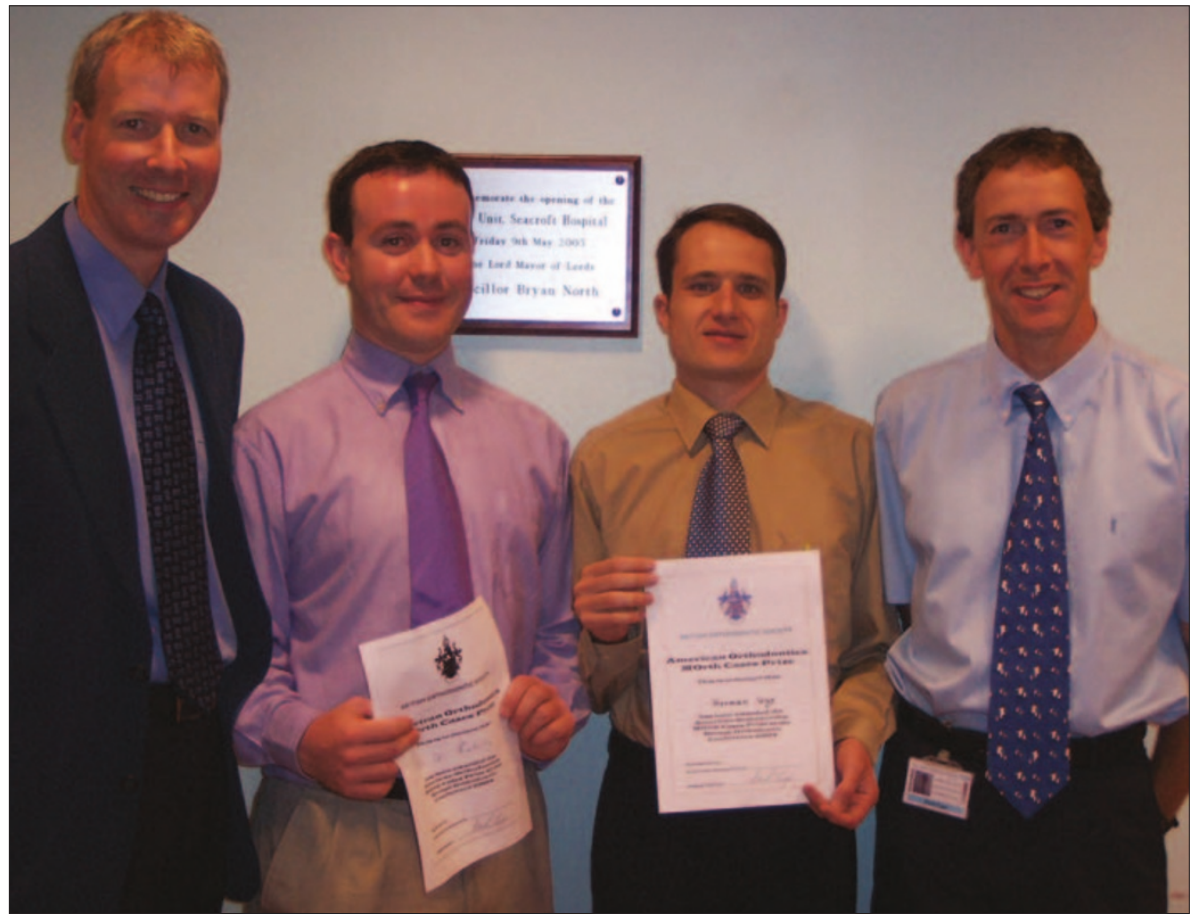

Staff members of the Orthodontic Department at Seacroft Hospital in Leeds are celebrating national recognition of their endeavours with a double award success at the recent 2004 British Orthodontic Conference in Harrogate. Gerard Rahilly (FITA in orthodontics), along with Paul Carr (chief maxillofacial technician) and David Morris (consultant orthodontist and trainer) were awarded 3rd prize for their poster presentation based on original research that compared articulator accuracy in orthognathic surgery planning. Herman Uys (specialist registrar) was awarded the M.Orth Cases prize for the best two treated orthodontic cases displayed at the conference. The award is judged on difficulty, clinical management and documentation. Pictured from left to right, David Morris, Gerard Rahilly, Herman Uys and Paul Carr.

\section{Mouth Cancer Awareness Week}

This week is Mouth Cancer Awareness week, which runs from the 7-13 of November.

According to the The British Dental Health Foundation, which co-ordinates the event, mouth cancer kills one person every five hours in the UK and the number of new cases is increasing quicker than any other cancer.

Health Secretary John Reid recently announced £300,000 would be made available over the next three years to

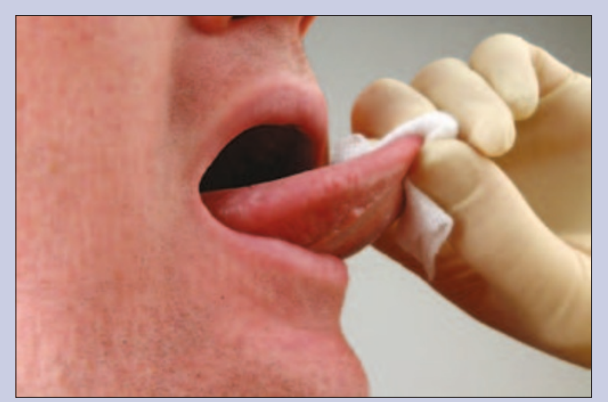

A soft tissue examination increase awareness of mouth cancer and the charity hopes that this investment could lead to a reduction in the number of deaths caused by the disease.

During the week long event, dentists can help by educating patients on how a healthy lifestyle can reduce the chances of them developing mouth cancer. This year's Mouth Cancer Awareness Week campaign, Conversation Killer, is focusing on the risks of smoking, drinking and poor diet, as well as emphasising the importance of early detection.

Resources, including patient information leaflets and the official Campaign Blue Ribbon, can be purchased from the Foundation by calling 08707704015 . Alternatively, visit www.dentalhealth.org/shop.

Mouth Cancer Awareness Week is backed by a wide range of national health organisations including Action on Smoking and Health (ASH), the British Dental Association, the British Association of Head and Neck Oncologists, the British Association of Oral and Maxillofacial Surgeons, Cancer Research UK, the health departments of the four UK countries, GKT, QUIT and Scope. 